\title{
Teachers' Perception on Use of Values Clarification Strategy for Curbing Examination Malpractice in Upper-Basic Schools in Ilorin Metropolis"
}

\author{
Rotimi W. Okunloye \\ Ph.D., Department of Social Sciences Education, University of Ilorin, Nigeria, \\ okunloye.rw@unilorin.edu.ng \\ Idayat N. Balogun \\ Department of Social Sciences Education, University of Ilorin, Nigeria, balogun.in@unilorin.edu.ng \\ Jumoke I. Oladele \\ Department of Social Sciences Education, University of Ilorin, Nigeria, oladele.ji@unilorin.edu.ng
}

\begin{abstract}
The study examined Social Studies teachers' perception of values clarification strategy for curbing examination mal-practice in upper basic schools in Ilorin Metropolis, Kwara state. The study adopted a descriptive survey design. The population for this study was all teachers in Upper Basic schools while the target population was Upper Basic Social Studies teachers sampled using the simple random and purposive sampling strategy. The instrument used for this study was a researcher-designed questionnaire, face and content validated by social studies experts and the reliability was determined using Cronbach's Alpha which yielded a coefficient of 0.76. Data obtained were analyzed using descriptive and inferential statistics. Results showed that different forms of examination malpractices are still prevalent in the Nigerian basic schools and teachers' awareness level of values clarification strategy for curbing the menace is moderate among others. It was recommended that values clarification strategy should be emphasized as a method for curbing examination mal-practices in basic schools and school proprietors and social studies and civic education teachers should address the challenges facing the use of values clarification for tackling examination malpractices.
\end{abstract}

Keywords: education, examination mal-practice, values clarification, social studies teachers

\section{INTRODUCTION}

Education in all ramifications ensures the acquisition and development of knowledge, skills and cultivation of values and attitudinal change that equip individuals for better living, functionality in society and positive contribution to societal development. Education in Nigeria is regarded as an instrument par excellence for effecting human capital and national development, (FGN, 2013). To actualize these goals, the National Policy on Education (NPE) recognized and stated as part of the core curriculum at all levels of the Nigerian education system for personal and societal problem solving to ensure that Nigeria become a fast and egalitarian society; a free and democratic society; united, strong and self-reliant; great and dynamic economic and land of bright and full opportunities for all citizens (FRN, 2013). Social studies were designed for the study of human and how he/she fits into a social

\footnotetext{
* Being a Paper Presented at $34^{\text {th }}$ annual National Conference of Social Studies Association of Nigeria (SOSAN) Held at University of Lagos, 26th $-29^{\text {th }}$ August, 2018.

Citation: Okunloye, R. W., Balogun, I. N., \& Oladele, J. I. (2019). Teachers' Perception on Use of Values Clarification Strategy for Curbing Examination Malpractice in Upper-Basic Schools in Ilorin Metropolis. Anatolian Journal of Education, 4(2), 10-18. https://doi.org/10.29333/aje.2019.422a
} 
group by utilizing the necessary attitudes, values and skills at his reach to make the planet earth better than he met it. Social Studies has been given a pride of place at all levels of Nigerian educational system as a means to achieving the corruption free, humane, moral and democratic society which Nigerians crave for (Opoh, Edinyang \& Ogbaji, 2014). Social Studies can thus help the Nigerian citizens generally to develop the ability to respect the worth and dignity of all human beings, help in the inculcation of national consciousness and national unity, instill in man a disposition for acceptance of attitudinal change or rebranding in order to tame the tide of corruption which has enveloped all sectors of life in Nigeria (Oyibe \& Nnamani, 2016).

For an individual to be awarded an academic certificate after passing through an educational institution, evaluation through examination is non-negotiable. Accordingly, paper and pencil test has become the major yardstick for gauging students' performance in the school system. According to Oko and Adie (2016), examination is an organized assessment or evaluation strategy which presents individual with a series of questions or tasks geared towards ascertaining the individual acquired knowledge and skills. It is one of numerous ways of evaluating students learning process. Amadi and Opuiyo (2018) explained that examination is part of evaluation in education aimed at determining a learner's level of intellectual competence and understanding after a given training. Therefore, examination is the pivotal point around which the whole system of education revolves and the success or failure of the system of examination is indeed an indicator of the success or failure of that particular system of education (Zakka, 2014). According to Zakka (2014) examinations vary in style and requirements. For example, in a closed book examination, an examinee is often required to rely upon memory to respond to certain items, whereas in open book examination, the examinee may use one or more supplementary materials in the course of the examination. It can also be formal or informal.

In educational system, world over, the examination process makes the difference in the actualization of the goals of education. The goals of national educational systems and indeed national development become a mirage if examination ethics are not strictly adhered to in the conduct of private and public examinations for selection, certification, recruitment, promotion and allied purposes. The significance of examination has been further reiterated by Njoku and Njoku (2016) who observed that examination still remains the best tool for an objective assessment and evaluation of what learners have achieved after a period of instruction. Therefore, any action that undermines examination poses a great threat to the validity and reliability of examination results and certification in any educational system. In spite of the emphasis on examination, some students still do not take their examination seriously while some prepare very seriously for it. Those who do not take their examinations seriously explore and device illegal and unethical alternative means of helping themselves out to pass. These include writing notes to the examination hall, writing on their palm and laps with tiny prints, smuggling of pre-answered examination questions into examination halls, copying from other students and recruiting other persons to write examination on their behalf (impersonation) among others; all termed as examination malpractice. Amadi and Opuiyo (2018) reiterated that copying, the use of textbook and phones, sorting of courses, paper leakage among others are forms of examination mal-practices indulged in by students.

Examination mal-practice as defined by West African Examination Council (WAEC) (2003) is an irregular behavior or act exhibited by candidates or anybody charged with the responsibility of conducting examination in or outside the examination hall, before, during or after such examination with the aim of taking undue advantage. Examination malpractice according to George and Ukpong (2013) is a social menace but some students today see it as an acceptable and recognizable means of passing examination at all levels of education, which seem to be a positive effective while the negative part of it is that a lot of students carry result that do not reflect their ability, which threatens the quality of graduates produced by the educational system (Jokthan, 2016). Examination Mal-practice Index (EMI) a measure for examination breaches, increased from $6.9 \%$ in 2005 to $7.5 \%$ in 2006, representing an increase of $0.3 \%$ annually (Joshua, Ekpoh, Edet, Joshua, \& Obo, n.d.). According to

Anatolian Journal of Education, October $2019 \bullet$ Vol.4, No.2 
Yekeen (2019) and Adedigba (2019) over 12,000 candidates who sat for the June/July Senior School Certificate Examinations (SSCE) conducted by NECO in 2018 cheated.

Nigeria has suffered huge losses as a result of endemic corruption which is evident in high crime rate and other indices of systemic social dis-integration. The unhealthy incidents of fraud, embezzlement, bribery and forgery perpetrated by Nigerians at home and abroad have earned the country the status of pariah nation in the international community. These corrupt practices, is believed to have started right from home to primary and secondary schools, had stalled the development of the nation (Zakka, 2014). The logical outcome of this trend according to Egbo (2015) has been the production of halfbaked secondary school graduates to pursue courses of study for which they are not well equipped at higher institutions of learning. Similarly, the South African society is experiencing an alarming increase in crime related incidence such as dishonesty, violence and injustice among others. These show a decline I morality. These problems are prevalent in the society at a time where progressive approach to education is encouraged characterised by giving learners the right to personal choices in moral matters through value clarification programmes (Mashishi, 1999). Darling (1994) observed that the progressive educational theory has to be understood as stemming from the radical dissatisfaction with the conservative educational practice where learner's educational development is not understood in terms of things that should be known, rules that must be follow as well as adult characteristics that ought to be adopted. As such, teachers are facilitators while learners are given considerable freedom and independence.

The development of a nation largely depends on the right type of values that are cherished and vigorously pursued and applied by majority of its citizens is an urgent imperative for citizens' capacity building and national development Although values vary from one place to another, from people to people and from one country to the other, there are universal values that are recognized generally, and accepted in human societies. These include honesty, hard work, justice and patriotism. Nigerian society has gradually relapsed in its adherence to laudable traditional values for which traditional societies of the pre-colonial era were known. These values have been greatly eroded and many antisocial vices have emerged which threaten to wipe out these cherished values. Values which may be described as those beliefs and norms of acceptable behaviors for good inter-personal and inter-group relationships This means value in this context is perceived as the determiners in individuals which influence the choice of what is desirable or undesirable, morally right or morally wrong and which ultimately direct individuals behavioural disposition (Mezieobi \& Danlad, 2012). Values clarification is asset of strategy's for teaching positive values and re-orientating individuals and groups who previously subscribe to and exhibit negative values (Mezieobi \& Danlad, 2012). Values clarification according to Akintude and Selzing-Musa (2016) is a pragmatic and effective approach for curbing examination malpractices and other social vices among children and youth in the school system.

Social studies focus on the study of human-environmental relationships for the purposes of citizenship education (Okunloye, 2007). Civic Education is another Social studies-related basic school subject in Nigerian schools which focuses knowledge acquisition, skills development and attitude and value cultivation for citizenship education, societal problem-solving and development (Okunloye, 2014). Its status in the basic school curriculum as a special subject for citizenship education, personal and societal problem solving involving the use of values clarification by teachers makes it appropriate to addressing the menace of examination malpractices in Nigeria basic schools (Okunloye, 2016). The Federal Government in a bid to tackle this ugly trend, which is gradually destroying the education system, promulgated a decree stipulating a jail term of 21 years to every offender (Federal Government of Nigeria (FGN), 1999). In spite of this extreme penalty, examination malpractice is still on the rise. If educationists and stakeholders do not pay adequate attention to the re-orientating the learners in basic and secondary schools on the acceptable norms of conduct in public examination to drastically reduce examination malpractices, the nation's educational standard is bound to further 
decline and as such, there is the need to explore other non-punitive or legalistic approach such as values clarification. AI-Shawan (2007) examined Values and Their Teaching Methods in Social Studies with emphasis on the importance of teaching values because of their close and strong relation to the affective domain. and their impact on the desired learning outcome. Ogundiran (2012) hinged value clarification strategy of social education as a tool for cultural improvement in Nigeria. The Kirschenbaum (2013) researched on values clarification in the context of counseling and psychotherapy. More recently, Ajitoni and Omiyefa (2017) studied civic education for value clarification and re-orientation in promoting nation building in Nigeria. None of these studies focused on of values clarification strategy for tackling examination malpractice and this is the gap this study is poised to fill. Therefore, this paper examined teachers' perception of values clarification strategy for tackling examination malpractice in upper basic schools in Ilorin Metropolis, Kwara State, Nigeria. To guide the study, the following research questions were formulated:

1.Are teachers aware of value clarifications as strategy for tackling examination for tackling examination malpractice in upper basic schools in Ilorin Metropolis?

2. What is the perception of teachers on the use of values clarification strategy for tackling examination malpractice in upper basic schools in Ilorin Metropolis?

3. What are the challenges faced by teachers in using values clarification strategy for tackling examination malpractice in upper basic schools in Ilorin Metropolis?

\section{METHOD}

The descriptive survey method was adopted for the study. Descriptive survey is considered the most appropriate design as it aided describing the perception of a given population within the study area through the use of questionnaire. The population for this study was all teachers in upper basic schools in Ilorin South LGA of Kwara State; while the target population was upper basic teachers. The simple random and purposive sampling employed. In the first stage, simple random strategy was used to select twenty upper basic schools after which the purposive sampling strategy was used to select all Social Studies and Civic education in selected schools constituted the sample for the study. A total of 200 teachers were involved in the study.

The instrumentation used for this study is a researcher-designed questionnaire prepared and administered to the respondents. The questionnaire comprises of 2 sections: section A and B. Section A was used to elicit information on student's demographic data and information, Section B was used to elicit information on perception of teachers of values clarification for eradicating examination malpractice. The section consisted 20 items scaled on a four-point Likert scale-type from strongly agree (SA), agree (A), disagree (D), strongly disagree (SA). The instrument was face and content validated by Social Studies and educational measurement experts to ascertain its content while the content was subjected to Cronbach's alpha reliability test of internal consistency. Based on Cronbach's alpha of 0.76 , the instrument was adjudged reliable for data collection for the study.

\section{FINDINGS}

Data obtained were analyzed using descriptive statistics, involving percentage strategy and frequent count using Statistical Package for Social-Sciences (SPSS 23.0).

Research Question One: Are teachers aware of values clarification strategy for tackling examination malpractice in upper basic schools in Ilorin Metropolis? 
Responses on teachers' awareness of values clarification strategy for curbing examination malpractice were categorized into high, moderate and low level which was analyzed using frequency and percentages as shown in table 3.

Table 3

Percentage Analysis of Awareness of Values clarification for tackling Examination Malpractice in Upper Basic schools in Nigeria

\begin{tabular}{lcc}
\hline Teachers' Awareness & Frequency & Percentage (\%) \\
\hline High level of Awareness & 74 & 37.0 \\
Moderate level of Awareness & 86 & 43.0 \\
Low level of Awareness & 40 & 20.0 \\
Total & 200 & 100.0 \\
\hline
\end{tabular}

The result in Table 3 indicated that, 74(37.0\%) teachers' level of awareness of values clarification strategy for tackling examination malpractice was high, 86(43.0\%) of teachers of awareness was average, while $40(33.0 \%)$ of teachers' level of awareness of the use of values clarification for tackling examination malpractice was low. This implies that teachers' level of awareness of values clarification to tackling examination malpractice was moderate in upper basic schools in Ilorin Metropolis.

Research Question Two: What is the perception of teachers on the use of values clarification strategies for tackling examination malpractice in upper basic schools in Ilorin Metropolis?

Responses on teachers' perception on the use of values clarification strategy for tackling examination malpractice were categorized into positive and negative which was analyzed using frequency and percentages as shown in table 4.

Table 4

Frequency and Percentage Analysis of Perception on Use of Values clarification for tackling Examination Malpractice in Upper Basic schools in Nigeria

\begin{tabular}{lcc}
\hline Teachers' Perception & Frequency & Percentage (\%) \\
\hline Positive & 157 & 78.5 \\
Negative & 43 & 21.5 \\
Total & 200 & 100.0 \\
\hline
\end{tabular}

The result in Table 4 indicated that, 157(78.5\%) teachers had a positive perception of values clarification strategy for tackling examination malpractice while $43(21.5 \%)$ teachers had a negative perception of values clarification strategy for tackling examination malpractice. This implies that teachers had a positive perception of values clarification strategy for tackling examination malpractice in upper basic schools in Ilorin Metropolis.

Research Question Three: What are the challenges faced by teachers in using values clarification strategies for tackling examination malpractice in upper basic schools in Ilorin Metropolis?

To answer research question three, mean as well as their rank order was used to analyze the data. Responses were graded on a four-point Likert scale. Items with a mean response of 2.5 and above were adjudges as challenges in using values clarification strategy by teachers as shown in Table 5 .

Table 5

Mean and Ranking Order of Challenges in using Values clarification by Teachers

\begin{tabular}{lcc}
\hline Challenges in Using Values clarification by Teachers & Mean & Ranking \\
\hline Low awareness of values clarification & 3.59 & $2^{\text {st }}$ \\
Lack of understanding of the strategy & 3.15 & $5^{\text {nd }}$ \\
Laziness & 3.60 & $1^{\text {st }}$ \\
Poor remuneration & 3.36 & $3^{\text {th }}$ \\
Over-populated classes & 3.32 & $4^{\text {th }}$ \\
\hline
\end{tabular}


As shown in Table 5, challenges in using values clarification by teachers in upper basic schools in Ilorin Metropolis were laziness with a mean score of 3.60 ranking first, low awareness of the effectiveness of values clarification with a mean score of 3.59 ranked second, poor remuneration with a mean score of 3.36 ranked third, over-populated classes with a mean score of 3.32 ranked fourth and lack of understanding of the strategy ranked fifth.

\section{CONCLUSION, DISCUSSION AND SUGGESTION}

In conclusion, while examination malpractice is still prevalent in the Nigerian basic schools, teachers' awareness level of moralistic approaches to curbing the menace is moderate while teachers' perception of values clarification was positive. Although, they faced myriad of challenges.

The finding revealed that teachers' awareness level of values clarification to curb examination malpractice was moderate. This finding is in agreement with that of Egbo (2015) who reported that teachers' awareness level of values clarification strategy for curbing examination malpractice in secondary schools in Enugu State to be moderate. According to Akintude and Selzing-Musa (2016), the vigorous campaigns and seminars, the need for adherence to examination ethics and positive values such as honesty, dedication to duty and study, hard work and perseverance among others seem to have raised the awareness level on the need to curb examination malpractice and other negative values in the school and society.

Another finding showed that teachers had a positive perception of values clarification strategy for tackling examination malpractice in upper basic schools in Ilorin Metropolis. This finding is in line with that of Uchekwe (2012) who reported that stakeholders' perception of strategies adopted for curbing examination malpractice was slightly effective. This finding do not concur with that of Ukpor (2005) who reported that student with negative self-concept doubts themselves and such student gets involved in examination malpractice. Alutu and Aluede (2006) also points to the fact that the majority of students have a wrong perception about examination ethics.

Furthermore, findings show that the challenges in using values clarification by teachers were laziness, low awareness of values clarification, poor remuneration, over-populated classrooms and lack of understanding of the strategy. This finding is in consonance with that of Oko and Adie (2016) who reported that the challenges of using values clarification in curbing examination malpractice in Ilorin Metropolis to include laziness, lack of preparation and lack of self-confidence.

The following are therefore suggested based on the study:

1.Examination malpractice should be emphasized as a moral dilemma and values clarification strategy for teaching social studies and civic education in upper basic schools should be employed.

2.Various education stakeholders should make concerted effort to raise teachers' awareness level of values clarification as a strategy for positive values clarification while maintaining a positive perception of values clarification as a strategy for tackling examination malpractice in schools.

All school proprietors; public and private should address the challenges of poor remuneration and high student-teacher ratio hindering the use of values clarification strategy in teaching Social Studies and Civic Education for addressing social vices including examination malpractices.

\section{REFERENCES}

Adedigb, A. (2019). NECO releases Nov/Dec 2018 SSCE results. Premium Times, February 8, 2019. Retrieved from: https://www.premiumtimesng.com/news/top- news/311330-just-in-necoreleases-nov-dec-2018-ssce-results.html 
Ajitoni, S. O., \& Omiyefa, M. O. (2017). Exploring civic education for value clarification and reorientation in promoting nation building in Nigeria. Journal of Educational Foundations, 7. Retrieved from https://www.ajol.info/index.php/jef/article/view/169266.

Akintude, O. O., \& Selzing-Musa, G. (2016). Pragmatic strategies of curbing examination malpractices in secondary schools in Nigeria. Asia Pacific Journal of Education, Arts and Sciences, 3(1), 110-115.

AI-Shawan A. M. (1997). Values and their Teaching Methods in Social Studies. Journal of Educational Sciences, 9(1), 151-184.

Alutu, N. G., \& Aluede, O. (2006). Secondary school's student's perception of examination malpractices and examination ethics. J. Hum. Ecol., 20(4): 295-300.

Amadi, E. C., \& Opuiyo, A. R. (2018). Forms and causes of examination malpractice among university students: A case of Rivers State University, Port Harcourt. International Journal of Innovative Education Research, 6(1), 37-41.

Banwo, F. (2006). Examinations malpractice in Nigerian educational system: The scope and implications on national development. Lead paper presented at the national workshop organized by the African University of Institute, Imeko, Ogun State, March 14th 16th.

Darling, J. (1994). Child centered approach and its critics. London: Paul Chapman.

Egbo, A. C. (2015). Counselling strategies for curbing examination malpractices in secondary schools in Enugu State, Nigeria. World Journal of Education, 5(3), 91-98.

Federal Government of Nigeria (FGN) (1999). Examination Malpractices Act 1999 No. 33.

Federal Government of Nigeria (FGN) (2013). National Policy on Education. Yaba, NERDC Press.

George, I. N., \& Ukpong, D. E. (2013). Contemporary social problems in Nigeria and its impact on national development: implication for guidance and counselling services. Journal of Educational and Social Research, 3(2), 167-173.

Joshua, M. T., Ekpoh, U. I., Edet, A. O., Joshua, A. M., \& Obo, F. E. (n.d.) Managing examination crisis: The menace of examination malpractice in Nigeria. Retrieved from http://citeseerx.ist.psu.edu/viewdoc/download;jsessionid=15F6F4470FC570857DF92B2509D1F46C? doi=10.1.1.610.4389\&rep=rep1\&type=pdf.

Kirschenbaum, H. (2013). Values clarification in counseling and psychotherapy: Practical strategies for individual and group settings. Oxford Scholarship Online. DOI: 10.1093/acprof:oso/9780199972180.001.0001.

Jokthan, E. T. (2016). Curbing examination malpractice in schools: Participative advocacy. JORIND 11(2), 125-131.

Mashishi, N. G. (1999). A critical analysis of the value clarification approach regarding moral values in the South African school context (Unpublished master thesis). Rand Afrikaans University, South Africa.

Mezieobi, K. A., \& Danlad, S. A. (2012). Chapter five: Value education. In K. A. Mezieobi (Ed.), New frontier areas in social studies in Nigeria. Owerri: Acadapeak.

Njoku, N. C., \& Njoku, D. I. (2016). Curbing examination malpractice in secondary schools in Nigeria through moral education. Research on Humanities and Social Sciences, 6(18), 161-169. 
Ogundiran, O. J. (2012). Cultural improvement in Nigeria: The value clarification strategy of social education as a tool. Nigerian Journal of Social Studies, 15(2), 100-110.

Oko, S. U., \& Adie, R. I. (2016). Examination malpractice: Causes, effects and possible ways of curbing the menace. A study of Cross River University of Technology. International Journal of Managerial Studies and Research (IJMSR), 4(1) 59-65.

Okunloye, R. W. (2007). Globalization, human rights and the challenges for the Nigerian junior secondary schools' social studies curriculum. Sokoto Educational Review (SER), 9(1), 1-9.

Okunloye, R. W. (2014, November). Nigerian basic school social studies curriculum development in retrospect: Any lesson for the new value education curriculum. A paper presented at the $30^{\text {th }}$ Annual National Conference of Social Studies Association (SOSAN) held at the University of Ibadan, Ibadan, Nigeria.

Omemu, F. (2015). Causes of examination malpractice in Nigeria schools. British Journal of Education, 3(7), 34-41.

Opoh, F.A., Edinyang, S. D., \& Ogbaji, D. I. (2014). Introduction of social studies education in Nigeria schools: A success or a failure. International J. of Education and Research, 2(4), 143-150.

Oyibe. O. A., \& Nnamani, S. C. (2016). Relevance of affective domain in social studies education for national development. International Journal of Education, Learning and Development, 4(7), 66-72.

Uchekwe, J. O. (2012). Stakeholders' perceptions of the effectiveness of the strategies adopted for curbing examination malpractice in public examinations in Nigeria (Unpublished master thesis). University of Nigeria, Nsuka.

Yekeen, A. (2019). 12,084 candidates arrested for examination malpractice in 2018 Nov/Dec NECO GCE. International Centre for Investigative Reporting. Retrieved from: https://www.icirnigeria.org/12084-candidates-arrested-for- examination-malpractice-in-2018-novdec-neco-gce/.

Zakka, J. (2014). Innovative strategies for curbing examination malpractices in public examinations in Nigeria (Unpublished master thesis). University of Nigeria, Nsuka.

West African Examination Council (WAEC) (2003). West Africa: WAEC Releases November/December 2003 WASSCE Results. 